\title{
Solitary osteochondroma of ischial ramus causing sciatic nerve compression
}

\author{
Siyatik sinir sıkışmasına yol açan iskiyon kolu soliter osteokondromu
}

Kemal Gökkuş, M.D., ${ }^{1}$ Ahmet Turan Aydın, M.D., ${ }^{1}$ Ergin Sağtaş, M.D. ${ }^{2}$

'Department of Orthopedics and Traumatology, Antalya Memorial Hospital, Antalya, Turkey

${ }^{2}$ Department of Radiology, Antalya Memorial Hospital, Antalya, Turkey

\begin{abstract}
We present a 25-year-old male case of osteochondroma originating from ischial ramus which causes sciatica. The pelvic involvement is rare. Iliac crest of the pelvis is often involved. Ischial ramus involvement is extremely rare. In this article, we presented a rare case of ischial ramus involvement that misleading the physician to L4-L5-S1 radiculopathy.

Key words: Osteochondroma; pelvis; sciatica.
\end{abstract}

Osteochondroma is the most common benign tumor reportedly accounting for $36 \%$ to $40 \%$ of all such tumors. ${ }^{[1]}$ It is characterized by a cartilage-capped osseous projection protruding from the surface of the affected bone. Osteochondroma is a hemartoma derived from an aberrant subperiostal germ of the physeal cartilage, which grows and matures according to normal enchondral ossification. ${ }^{[2]}$ Although originating in early infancy, the exostosis is usually first noticed between 6-20 years of age. ${ }^{[2]}$ Osteochondroma is most commonly seen in males with a male/female ratio of 2:1. ${ }^{[2]}$ The most frequent location is in the long bones of the limbs, distal femur, proximal humerus, and proximal tibia in that order. ${ }^{[2-5]} \mathrm{A}$ pelvic location is rare. In the pelvis the iliac crest is usually involved. An ischial ramus location is extremely rare. We present a case of osteochondroma originating from the ischial ramus that caused sciatica.

\section{CASE REPORT}

Our patient was a 25-year-old male with 10 years of radiating pain and sciatalgia in the right extremity. The
Bu makalede iskion kolundan köken alıp siyataljiye yol açan 25 yaşında bir erkek olgu sunuldu. Pelvik tutulum nadirdir. Sıklıkla pelvisin iliyak kanatlarında tutuluma rastlanır. İskion kolunun tutulumu oldukça nadirdir. Bu yazıda hekimi L4-L5-S1 radikülopatiye yönelten, nadir iskion kolu tutulumu sunuldu.

Anahtar sözcükler: Osteokondrom; pelvis; siyatik.

pain worsened when he was sitting. Nonsteroidal antiinflammatory drugs provided minimal relief.

On physical examination the patient was a healthy-looking individual, although limping on the right side. There was tenderness around the ischial tuberosity. Right side hip flexion contracture (5-10 degrees) was detected without limited hip rotational motions. Fabere test was positive. The Lasegue test was positive at 60-70 degrees angle on the right side and pain with resisted flexion of the hip was detected. The neurologic examination revealed that the patient had radiating pain and paresthesia at the ipsilateral lower extremity, and also weakness at the plantar flexion of the foot.

Plain radiography (Figure 1) and computed tomography (CT) scan revealed an exostotic projection composed of dense calcification of the cartilaginous cap from right ischial ramus. On the CT scan, one can see that in comparison with the normal side (arrow 1), the sciatic nerve on the affected side (arrow 2) is pushed from the femoroischial line (Figure 2).

- Received: October 30, 2012 Accepted: January 15, 2013

- Correspondence: Kemal Gökkus, M.D. Memorial Antalya Hastanesi Ortopedi ve Travmatoloji Bölümü, 07090 Kepez, Antalya, Turkey. Tel: +90 242 - 3146666 / $4131 \quad$ Fax: +90 242 - 3441678 e-mail: kgokkus@yahoo.com 


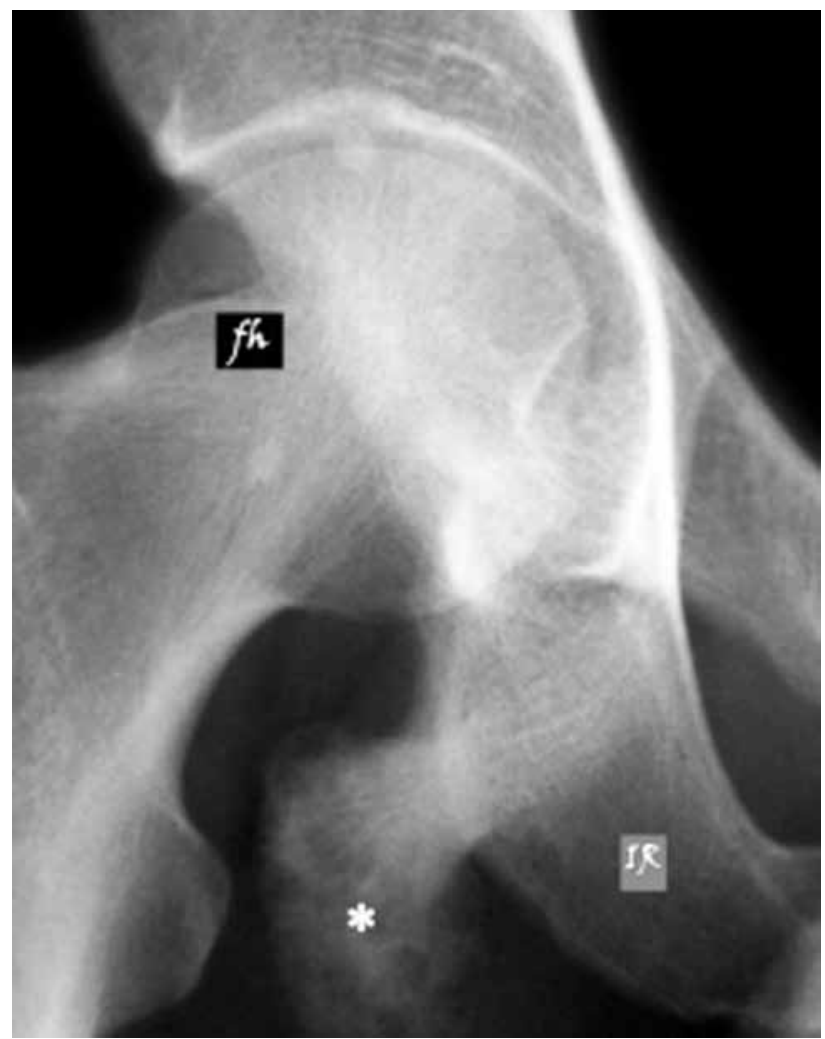

Figure 1. Plain radiography shows an ischial ramus originated osteochondroma. Note the typical stalk-like (exostotic) protuberance on the bone. fh: Femoral head; Ir: Ischial ramus; *: Stalk-like (exostotic) protuberance.

Axial MRI scan showed an approximately eggsized, exophytic calcified mass with cartilage cap with irregular margins.

En-bloc excision was performed via the modified Gibson incision in which the curved part of the

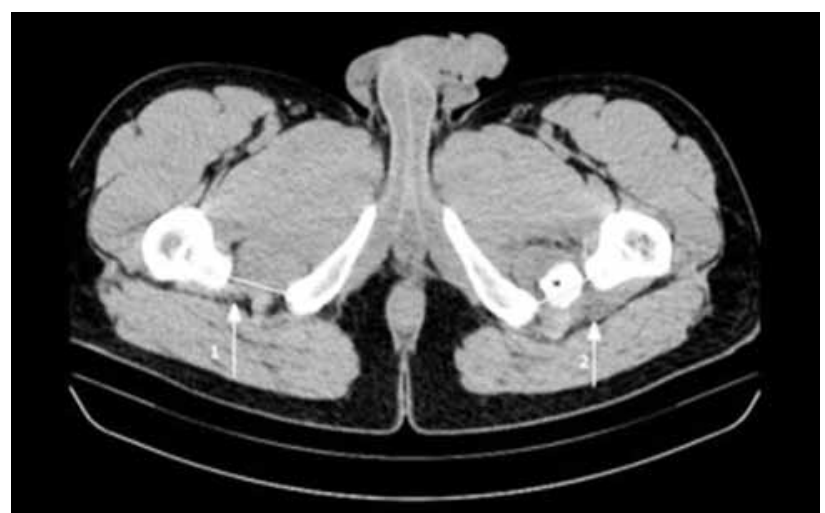

Figure 2. Normal side sciatic nerve (arrow 1), affected side sciatic nerve (arrow 1), osteochondroma of ischial ramus (asterisk). Note the distance between the femora-ischial line and sciatic nerve is different between the affected side and normal side. The affected sciatic nerve was pushed posteriorly by the osteochondroma (arrow 2). incision was lowered to approach the ischial tuberosity. Postoperatively, the patient's radiating pain and paresthesia were completely gone and neurologic symptoms were improved. Subsequent pathology reports showed no evidence of malignancy and were consistent with osteochondroma (Figure 3).

\section{DISCUSSION}

The involvement of the pelvic bone is rare. Unlike limb involvement, in pelvic involvement the symptomatology can change into an unusual course. Wang et al. ${ }^{[6]}$ reported pubic osteochondromas that cause bladder outlet obstruction. Carpintero et al. ${ }^{[7]}$ reported another case with unusual symptomatology that caused discomfort during sexual intercourse secondary to pubic osteochondroma. In our case, the symptomatology was associated with the ischial ramus, because the patient's problem was caused by sitting. The ischial ramus is also called the sitting bone.

The anatomic relationship between sciatic nerve and ischial spine is crucial to understand the symptomology of ischial rami-originated masses. The sciatic nerve, a branch of the sacral plexus (L4 and 5; S1, 2, and 3), emerges from the pelvis through the lower part of the greater sciatic foramen. It is the largest nerve in the body and consists of the tibial and common peroneal nerves bound together with fascia. The sciatic nerve appears below the piriformis muscle, curving laterally and downwards, lying successively on the root of the ischial spine. ${ }^{[8]}$

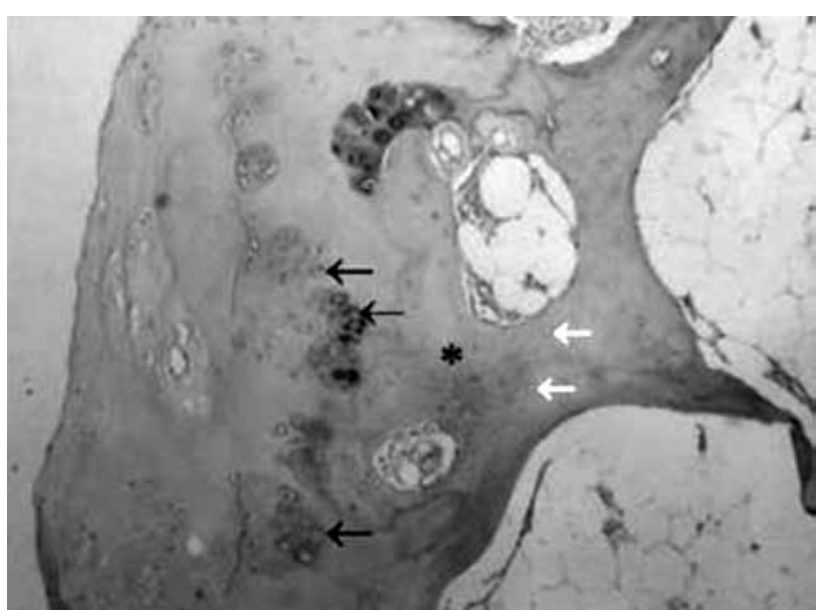

Figure 3. A histologic preparation of a synovial solitary osteochondroma ( $\mathrm{H}-\mathrm{E} \times 4 \mathrm{obj}$.) revealed the characteristic pattern of an osteochondroma which is covered by a thick cartilaginous cap formed with columnar arrangement of chondrocytes (black arrows) which is typical for osteochondroma. At the chondroosseous junction, osteoid matrix (asterisk) with osteocytes (white arrows) forming bony trabecula is apparent at the base of the cap. 
This anatomic pathway shows us close relationship between the ischial ramus and sciatic nerve.

In the literature several cases have been published about osteochondroma related to sciatica. None of them originated from the ischial ramus like this case. Two of them originated from the femoral neck and the rest of them originated from the iliac crest and spinal canal that compressed nerve roots, mimicking L3-L5-S1 radiculopathy. ${ }^{[9-12]}$ To the best of our knowledge, the ischial ramus location that causes sciatica has not been reported either. In the series of Campanacci ${ }^{[2]} 1117$ cases were reported; and only three cases dealt with the ischial ramus, none of them connected with sciatica.

Preoperative planning is crucial before surgery. In this case a modified Gibson approach was used and the posterior curve of the modified Gibson approach lowered to expose the ischial ramus-located osteochondroma and sciatic nerve.

The other causes of sciatica like ischial tuberosity bursitis, L4-5-S1 radiculopathy and piriformis syndrome must be among the differential diagnoses and must be ruled out with physical examination and radiological evidence.

Magnetic resonance imaging (MRI), Electromyography and CT are especially important diagnostic tools to understand the true reason for sciatica.

Especially in this anatomic location, ruling out tumors or tumor-like conditions that can mimic osteochondroma is very important. Those are myositis ossificans and chondrosarcoma.

On plain radiographs, chondrosarcoma is a fusiform, lucent defect with scalloping of the inner cortex and periosteal reaction. Extension into the soft tissue may be present as well as punctate or stippled calcification of the cartilage matrix $\cdot{ }^{[13]}$

In our case a typical stalk-like (exostotic) protuberance on the bone is demonstrated. Computed tomography is helpful in defining the integrity of the cortex and distribution of calcification. Magnetic resonance imaging is valuable in surgical planning as it demonstrates the intraosseous and soft tissue involvement of the tumor. Magnetic resonance imaging is also helpful in evaluating possible malignant degeneration of osteochondromas by allowing accurate measurements of the cartilage cap which should be less than $2 \mathrm{~cm}$ thick. ${ }^{[14]}$

In malignant transformation of osteochondroma to chondrosarcoma (so-called exostotic chondrosarcoma), the most reliable clinical and radiologic features include pain (in the absence of fracture, bursitis, or pressure on nearby nerves), the growth spurt of osteochondroma (after skeletal maturity), development of a bulky cartilaginous cap (thicker than $2 \mathrm{~cm}$ ), dispersed calcifications in the cartilaginous cap (which in benign exostosis are confined to the osteochondral junction), and development of a soft tissue mass. ${ }^{[14-17]}$ Scintigraphy is not a reliable modality for differentiation of benign exostoses from exostotic chondrosarcoma. ${ }^{[14,15,18]}$

The radiologic features of myositis ossificans are "faint soft tissue calcification within two to six weeks, ${ }^{[19]}$ (May have well-defined bony margins by 8 weeks ${ }^{[19]}$ separated from periosteum by lucent zone. Computed tomography: Characteristic feature is peripheral ossification." ${ }^{\prime 20]}$ In our case CT and plain radiologic findings showed that the bony protuberance was stalk-like and different from myositis ossificans. Therefore, ruling out myositis ossificans was very easy in this case.

In conclusion, surgical en-bloc excision is the treatment of the choice for symptomatic osteochondroma. The ischial ramus is a rare location for osteochondroma but must be kept in mind in the differential diagnosis of sciatica.

\section{Declaration of conflicting interests}

The authors declared no conflicts of interest with respect to the authorship and/or publication of this article.

\section{Funding}

The authors received no financial support for the research and/or authorship of this article.

\section{REFERENCES}

1. Dahlin CD, Krishanan KU. General aspects and data on 8542 cases. In: Thomas CC, editor. Bone tumors. Illinois: Springfield; 1986. p. 18-32.

2. Campanacci M. In: Enneking WF, editor. Bone and soft tissue tumors. Exostosis Piccin Nuoava Libraria, Padova: Springer-Verlag; 1998. p. 179-96.

3. Ermiş MN, Aykut US, Durakbaşa MO, Ozel MS, Bozkuş FS, Karakaş ES. Snapping scapula syndrome caused by subscapular osteochondroma. Eklem Hastalik Cerrahisi 2012;23:40-3.

4. Atik OS, Sarikaya B, Kunat C, Muradi R, Ocaktan B, Topçu H. Osteochondroma of the talus. Eklem Hastalik Cerrahisi 2010;21:116-7.

5. Marya KM, Kundu ZS, Sangwan SS. Synostotic osteochondroma of 4th and 5th metacarpal. Eklem Hastalik Cerrahisi 2003;14:176-17.

6. Wang WY, Du LD, Lv WC, Tian Y, Shao Q, Zhang YH. Osteochondroma of the symphysis pubis: a rare cause of bladder outlet obstruction. Am Surg 2010;76:916-8.

7. Carpintero P, Urbano D, Segura M, de Tembleque FR, 
Saceda JL. Discomfort during sexual intercourse secondary to osteochondroma: a report of two cases. Joint Bone Spine 2007;74:401-3.

8. Richard S. Snell. Lower limb. In: Snell RS, editor. Clinical anatomy by regions. 8th ed. Philedelphia: Lipincott Williams \& Wilkins; 2008. p. 550-663.

9. Kim WJ, Kim KJ, Lee SK, Choy WS. Solitary pelvic osteochondroma causing L5 nerve root compression. Orthopedics 2009;32:922. doi: 10.3928/01477447-20091020-25.

10. Turan Ilica A, Yasar E, Tuba Sanal H, Duran C, Guvenc I. Sciatic nerve compression due to femoral neck osteochondroma: MDCT and MR findings. Clin Rheumatol 2008;27:403-4.

11. Yu K, Meehan JP, Fritz A, Jamali AA. Osteochondroma of the femoral neck: a rare cause of sciatic nerve compression. Orthopedics 2010;33. doi: 10.3928/01477447-20100625-26.

12. Ohtori S, Yamagata M, Hanaoka E, Suzuki H, Takahashi $\mathrm{K}$, Sameda H, et al. Osteochondroma in the lumbar spinal canal causing sciatic pain: report of two cases. J Orthop Sci 2003;8:112-5.

13. DeGroot Henry MD. Available from: http://www. bonetumor.org/tumorscartilage/chondrosarcoma. [Accessed 15 jun 1999]
14. Peter G. Bullough. Orthopaedic pathology. In: Vosburgh A, editor. Osteochondroma. New-York. Mosby-Elsevier; 2010. p. 525-7.

15. Norman A, Sissons HA. Radiographic hallmarks of peripheral chondrosarcoma. Radiology 1984;151:589-96.

16. Hudson TM, Springfield DS, Spanier SS, Enneking WF, Hamlin DJ. Benign exostoses and exostotic chondrosarcomas: evaluation of cartilage thickness by CT. Radiology 1984;152:595-9.

17. Malghem J, Vande Berg B, Noël H, Maldague B. Benign osteochondromas and exostotic chondrosarcomas: evaluation of cartilage cap thickness by ultrasound. Skeletal Radiol 1992;21:33-7.

18. Adam G. Cartilage (Chondrogenic) lesions. In: Jundt G, Remagen W, Adam G, editors. Differential diagnosis in orthopaedic oncology. Philedelphia: Lippincott Williams \& Wilkins; 2007. p. 240-1.

19. Crundwell N, O'Donnell P, Saifuddin A. Non-neoplastic conditions presenting as soft-tissue tumours. Clin Radiol 2007;62:18-27.

20. Parikh J, Hyare H, Saifuddin A. The imaging features of post-traumatic myositis ossificans, with emphasis on MRI. Clin Radiol 2002;57:1058-66. 